\title{
Beef Tallow Diet Decreases Lipoprotein Lipase Activities in Brown Adipose Tissue, Heart, and Soleus Muscle by Reducing Sympathetic Activities in Rats
}

\author{
Tatsuhiro MAtsuo and Masashige SuZuKI \\ Division of Nutrition and Biochemistry, Sanyo Women's College, \\ Hatsukaichi 738, Japan \\ ${ }^{1}$ Institute of Health and Sport Sciences, University of Tsukuba, \\ Tsukuba 305, Japan
}

(Received June 30, 1994)

\begin{abstract}
Summary Effects of dietary fats consisting of different fatty acids on lipoprotein lipase activities in the interscapular brown adipose tissue, heart, and soleus muscle, and on body fat accumulation were studied in rats. Sprague-Dawley male rats were meal-fed an isoenergetic diet based on either beef tallow or safflower oil for 8 weeks. Lipoprotein lipase activities in the interscapular brown adipose tissue, heart, and soleus muscle before and after a meal were lower in the beef tallow diet group than in the safflower oil diet group. Body fat accumulation was greater in the beef tallow diet group than in the safflower oil diet group. The norepinephrine turnover rates in the interscapular brown adipose tissue, heart, and soleus muscle were lower in the beef tallow diet group. $\beta$-Adrenergic receptor bindings were determined with $\left[{ }^{125} I\right]$ iodocyanopindolol. Binding affinities of $\beta$-adrenergic receptor in the interscapular brown adipose tissue, heart, and soleus muscle were lower in the beef tallow diet group probably resulted from lower membrane fluidities. These results suggest that intake of the beef tallow diet promotes body fat accumulation by reducing the lipoprotein lipase activities resulting from lower sympathetic activities in the brown adipose tissue, heart, and skeletal muscle.
\end{abstract}

Key Words lipoprotein lipase, norepinephrine turnover, adrenergic receptor, brown adipose tissue, heart, soleus muscle, membrane fluidity, beef tallow, safflower oil, body fat, rat

Lipoprotein lipase (LPL; EC 3.1.1.34) has its physiological site of action at the luminal surface of capillary endothelial cells where the enzyme hydrolyzes the triacylglycerol component of circulating lipoprotein particles, chylomicrons and very low density lipoproteins, to provide free fatty acids and 2-monoacylglycerol for tissue utilization (1-3). LPL, therefore, plays a primary role in triacylglycerol 
metabolism and is widely distributed in both white and brown adipose tissues, heart, and skeletal muscle $(4,5)$. Since fat oxidation is carried out mainly in brown adipose tissue, heart, and skeletal muscles, reduction of LPL activities in these tissues accelerates body fat accumulation. On the other hand, LPL activity in brown adipose tissue, heart, and soleus muscle are increased by $\beta$-adrenergic stimulation (e.g., cold exposure (4-7) and norepinephrine (NE) injection (5)). These results suggested that reductions of sympathetic activities in the brown adipose tissue, heart, and skeletal muscle promote body fat accumulation by decreasing the LPL activities in these tissues.

We have recently reported that when rats were meal-fed isoenergetic diets (45\% of energy as fat) based on beef tallow (rich in saturated and monounsaturated fatty acids) or safflower oil (rich in $n-6$ polyunsaturated fatty acid) for 4 months, LPL activities in the heart and soleus muscle were lower in rats fed a beef tallow diet than in these fed a safflower oil diet, and consequently greater body fat was accumulated in the former (8). However, LPL activities in the brown adipose tissue has not been examined. Since fat is oxidized primarily in the brown adipose tissue, it is necessary to check LPL activity in the brown adipose tissue. In addition, it is necessary to examine the early effects of beef tallow diet or safflower oil diet on LPL activities in the brown adipose tissue, heart, and skeletal muscle to confirm that reduction of LPL activities in these tissues causes body fat accumulation. Although the mechanism of the reduction in LPL activities by beef tallow has not been clarified, beef tallow might reduce sympathetic activities in various tissues.

In the present study, we examined 1) whether beef tallow diet feeding for 8 weeks reduces LPL activities in the interscapular brown adipose tissue (IBAT), heart, and soleus muscle; 2) $\beta$-adrenergic receptor binding and norepinephrine (NE) turnover rates in the IBAT, heart, and soleus muscle to determine whether beef tallow diet reduces sympathetic activities of these tissues in rats; 3 ) membrane fluidities of these tissues to identify possible mechanisms of changing of $\beta$ adrenergic receptor bindings.

\section{EXPERIMENTAL}

All procedures involving animals were approved by the Experimental Animal Care Committee of the University of Tsukuba.

Experiment 1: Effects of the dietary fats on lipoprotein lipase activities, $\beta$ adrenergic receptor binding in various organs, and body fat accumulation in rats. Animals and diets: Forty male Sprague-Dawley rats (5 weeks old) were obtained from CLEA Japan (Tokyo). One-half of the animals were fed a safflower oil diet and the other half were fed a beef tallow diet. The compositions of both diets have been described previously (8). Both diets provided 45, 35, and 20\% of energy as fat, carbohydrate, and protein, respectively. The metabolizable energy was 19.7 $\mathrm{kJ} / \mathrm{g}$ for the safflower oil diet and $18.4 \mathrm{~kJ} / \mathrm{g}$ for the beef tallow diet. Fatty acid compositions of safflower oil and beef tallow have been described previously ( 8 ); 
beef tallow consisted of $44 \%$ oleic, $27 \%$ palmitic, and $18 \%$ stearic acids and safflower oil consisted of $79 \%$ linoleic acid.

Experimental design: The animals were individually caged at $22 \pm 2{ }^{\circ} \mathrm{C}$, with light from $07: 00$ to 19:00. Each group of rats was meal-fed the diet at 08:00$09: 00$ and 20:00-21:00 and given free access to water for 8 weeks. Both groups of rats were given equal amounts of metabolizable energy during the experimental period. The meal-feeding method was used to adjust the energy intake between the two dietary groups. Under meal-feeding conditions, feeding one meal (within $2 \mathrm{~h}$ ) a day makes the food intake of the animals decrease, however feeding two meals a day used in this study minimized this decrease. The food consumption of rats shown in Table 1 was approximately the maximal amount of diet that rats could consume under the meal-feeding conditions. On the final day of the experiment, half of the rats in each diet group were killed by decapitation at 08:00 (before the meal), and the remaining rats were killed at 10:00 (after the meal). Blood was collected to obtain serum, which was stored at $-50^{\circ} \mathrm{C}$ until use. The IBAT, heart, soleus muscle, and abdominal adipose tissues (epididymal, perirenal, and mesenteric adipose tissues) were removed and weighed, and were stored at $-80^{\circ} \mathrm{C}$ until use. Carcass samples were obtained by removing head, liver, lungs, kidneys, spleen, testes, pancreas, and digestive tracts and were stored at $-20^{\circ} \mathrm{C}$ until analysis of carcass composition.

Serum and carcass analyses: Serum glucose and triacylglycerol were determined enzymatically using kits, glucose C-II Test and Triglyceride G Test, respectively, purchased from Wako Pure Chemical Industries (Osaka). Serum insulin was determined by an enzyme immunoassay using a kit (insulin EIA kit) purchased from Sanko Junyaku Co., Ltd. (Tokyo). Carcass fat and protein were analyzed by the method of Mickelsen and Anderson (9).

LPL activities of various tissues : LPL activities of the IBAT, heart, and soleus muscle were measured. The tissues were prepared by the method of Mori et al. (10). The substrate for LPL was prepared according to the method of Nilsson-Ehle and Schotz (11), but using unlabeled triolein. The LPL activity assay was

Table 1. Food consumption of rats fed both experimental diets. ${ }^{1}$

\begin{tabular}{lc}
\hline Experimental period (week) & Food consumption $(\mathrm{MJ} /$ week) \\
\hline 1 & 1.69 \\
2 & 2.32 \\
3 & 2.42 \\
4 & 2.52 \\
5 & 2.40 \\
6 & 2.49 \\
7 & 2.49 \\
8 & 2.49 \\
Total & 18.82 \\
\hline
\end{tabular}

${ }^{1}$ Values were calculated as the metabolizable energy of the diets. 
performed by incubation of the extract with the substrate at $37^{\circ} \mathrm{C}$ for $30 \mathrm{~min}(11)$. The free fatty acids released during the incubation were measured enzymatically using NEFA C Test purchased from Wako Pure Chemical Industries. One unit of LPL activity is defined as the amount which catalyzes the release of $1 \mu \mathrm{mol}$ free fatty acid per hour at $37^{\circ} \mathrm{C}$.

Preparation of plasma membranes: To prepare plasma membranes for fatty acid composition, membrane fluidity, and adrenergic receptor binding assay, IBAT was prepared as reported previously (12). Briefly, adipose tissues were homogenized with a glass homogenizer in 10 volumes of $50 \mathrm{mM}$ Tris- $\mathrm{HCl}$ buffer containing $5 \mathrm{mM} \mathrm{MgCl}$ and $145 \mathrm{mM} \mathrm{NaCl}(\mathrm{pH} \mathrm{7.6)}$ and centrifuged at $900 \times g$ for $10 \mathrm{~min}$ at $4^{\circ} \mathrm{C}$. The supernatant was centrifuged at $11,500 \times g$ for $20 \mathrm{~min}$ at $4^{\circ} \mathrm{C}$. Then, the supernatant was centrifuged at $49,000 \times g$ for $60 \mathrm{~min}$ at $4^{\circ} \mathrm{C}$. The pellet was resuspended in $50 \mathrm{~mm}$ Tris- $\mathrm{HCl}$ buffer and membranes were immediately used in analysis. Membranes of heart and soleus muscle were prepared from frozen tissue in a manner similar to the preparation of IBAT membranes except the homogenate was centrifuged at $49,000 \times g$ for $15 \mathrm{~min}$ at $4{ }^{\circ} \mathrm{C}$. Protein was determined by the method of Bradford (13).

Lipid extraction: The membrane suspensions were freeze-dried, and then total lipid was extracted from membranes by the method of Folch et al. (14). The fatty acid composition of total lipid was determined after hydrolysis and methylation according to the method of Nelson et al. (15) using a gas-liquid chromatograph system (Shimadzu Corp., Kyoto, Japan, Model GC-7AG). The system was equipped with a fused silica, wall-coated capillary column, $0.25 \mathrm{~mm}$ inner diameter $\times 25 \mathrm{~m}$ long, coated with ULBON HR20 (Shimadzu).

Fluorescence polarization: Membrane fluidity was assessed by fluorescence polarization using the lipid soluble fluorophore 1,6-diphenyl-1,3,5-hexatriene (DPH) as modified by the method of Nicolas et al. (16). A diluted aliquot containing $50 \mu \mathrm{g}$ protein $/ \mathrm{ml}$ from the membrane fraction in Tris- $\mathrm{HCl}$ buffer (pH 7.6) was incubated at $37^{\circ} \mathrm{C}$ for $30 \mathrm{~min}$ with $1 \mu \mathrm{l}$ of DPH. The probe was initially dissolved in tetrahydrofuran. The final concentration in the incubated medium was $2 \mu \mathrm{M}$.

Steady state fluorescence polarization studies were performed at $25^{\circ} \mathrm{C}$ using a fluorescence spectrophotometer (HITACHI, Tokyo, Japan, Model F-2000). The excitation wavelength was $361 \mathrm{~nm}$, the emission was detected at $431 \mathrm{~nm}$. The degree of fluorescence polarization $\mathbf{P}$ was calculated from Shinitzky and Barenholz (17).

$\beta$-Adrenergic receptor binding assay: Radioligands were incubated with the membrane preparations in a total volume of $0.25 \mathrm{ml}$. Incubations were stopped by cooling on ice, followed by rapid vacuum filtration onto Whatman $\mathrm{GF} / \mathrm{C}$ filters, which were then washed with $20 \mathrm{ml}$ Tris- $\mathrm{HCl}$ buffer. Non-specific binding was defined as binding of radioligand in the presence of an excess concentration of a specific displacing agent, $1 \mu \mathrm{M}$ propranolol (Wako Pure Chemical Industries). $\beta$-Receptor binding was evaluated with $5-1,000 \mathrm{pM}\left[{ }^{125} \mathrm{I}\right]$ iodocyanopindolol (Amer- 
sham, Buckinghamshire, England; specific activity $2,000 \mathrm{Ci} / \mathrm{mmol}$ ) as modified by Bylund and Snyder (18), and a 90-min incubation at $37^{\circ} \mathrm{C}$. Non-specific binding of $\left[{ }^{125} \mathrm{I}\right]$ iodocyanopindolol constituted 5-20\% of total binding. $\beta$-Adrenergic receptor number and binding affinity were determined from Scatchard analysis (19).

Experiment 2: Effects of dietary fats on the sympathetic activities of various organs. Animals, diets, and experimental design: Forty-two male SpragueDawley rats ( 5 weeks old) were obtained from CLEA Japan. All of the experimental conditions (diet compositions, housing conditions, feeding methods, etc.) were the same as in experiment 1 . The food consumption of rats was similar to that in experiment 1 (Table 1). On the final day, rats in each diet group were fed a meal at $08: 00-09: 00$. Then, 14 rats in each diet group were injected with the tyrosine hydroxylase inhibitor $\alpha$-methyl-p-tyrosine $(300 \mathrm{mg} / \mathrm{kg}$, i.p.) at $0 \mathrm{~h}(10: 00)$ and decapitated at $1.5 \mathrm{~h}$ or at $3 \mathrm{~h}$ after injection of $\alpha$-methyl-p-tyrosine, whereas 7 rats in each diet group received saline as controls at $0 \mathrm{~h}$ and immediately killed by decapitation. The IBAT, heart, and soleus muscle were removed and weighed, and were stored $-80^{\circ} \mathrm{C}$ until analysis of $\mathrm{NE}$ turnover rates. Carcass samples were collected and stored as described in experiment 1.

NE contents and turnover: NE contents of the IBAT, heart, and soleus muscle were assayed by HPLC with electrochemical detection (Shimadzu Corp., Kyoto, Japan, Model LC-6A) as modified by Refshauge et al. (20). NE turnover was estimated by a method reported previously (21). Saline-treated rats were used for the measurement of basal tissue level of NE (NE0). Since there is a monoexponential decline of tissue NE levels after the $\alpha$-methyl-p-tyrosine treatment, these data were then subjected to a least-squares linear regression analysis of log NE concentration versus time. Turnover rates (slope $/ 0.434 \times$ initial NE concentration) were estimated from these data.

Carcass analyses: Carcass fat and protein were assayed as in experiment 1.

Statistical analysis: In experiment 1, statistical differences in body weight, tissue weights, carcass composition, fatty acid composition of plasma membrane, fluorescence polarization, and $\beta$-receptor binding were analyzed by Student's $t$-test. The statistical difference in serum components and LPL activities were analyzed by two-way ANOVA and Scheffe's test (22). In experiment 2, NE turnover rates were analyzed by Student's $t$-test.

\section{RESULTS}

Experiment 1: Effects of the dietary fats on lipoprotein lipase activities, $\beta$-adrenergic receptor binding in various organs, and body fat accumulation in rats

Body weight, body fat, and tissue weights. Both groups of rats had the same body weight gain during the 8 weeks experimental period (Table 2). After killing the rats, body fat was measured. Abdominal adipose tissue weight was significantly larger in the beef tallow diet group than in the safflower oil diet group $(p<0.05)$ (Table 2). The carcass fat content was significantly greater in the beef tallow diet 
Table 2. Effect of the dietary fats on body weight, tissue weights, and carcass composition. ${ }^{1}$

\begin{tabular}{|c|c|c|}
\hline & \multicolumn{2}{|c|}{ Diet group } \\
\hline & Safflower oil & Beef tallow \\
\hline \multicolumn{3}{|l|}{ Body weight } \\
\hline Initial (g) & $140 \pm 1$ & $137 \pm 1$ \\
\hline final (g) & $425 \pm 4$ & $422 \pm 4$ \\
\hline Gain (g) & $285 \pm 4$ & $235 \pm 4$ \\
\hline \multicolumn{3}{|l|}{ Tissue weights } \\
\hline BAT (mg) & $456 \pm 15$ & $451 \pm 11$ \\
\hline Heart (mg) & $1,134 \pm 19$ & $1,050 \pm 15$ \\
\hline Soleus (mg) & $320 \pm 6$ & $309 \pm 7$ \\
\hline WAT (g) & $21 \pm 1$ & $26 \pm 1 *$ \\
\hline Carcass weight (g) & $279 \pm 3$ & $273 \pm 3$ \\
\hline Carcass fat $(\mathrm{g})$ & $40 \pm 2$ & $54 \pm 3^{*}$ \\
\hline$(\%)$ & $14 \pm 1$ & $20 \pm 1^{*}$ \\
\hline Carcass protein $(\mathrm{g})$ & $70 \pm 1$ & $67 \pm 2$ \\
\hline$(\%)$ & $25 \pm 1$ & $24 \pm 1$ \\
\hline
\end{tabular}

group than in the safflower oil diet group $(p<0.05)$, whereas the carcass protein contents of two diet groups were the same (Table 2). The IBAT, heart, and soleus muscle weights were not different between two dietary groups (Table 2).

Serum glucose, insulin, and triacylglycerol concentrations. The serum glucose, insulin, and triacylglycerol concentrations increased because of meal ingestion in both groups of rats $(p<0.05)$. The serum glucose concentrations before and after a meal were not different between the two groups (Table 3). The serum insulin and the triacylglycerol concentrations before and after a meal were higher in the beef tallow diet group than in the safflower oil diet group $(p<0.05)$ (Table 3).

LPL activities of various tissues. LPL activities in the brown adipose tissue before and after a meal were significantly lower in the beef tallow diet than in the safflower oil diet $(p<0.05)$, and it increased significantly with meal ingestion $(p<$ 0.05) (Fig. 1). LPL activities in the heart before and after a meal were significantly lower in the beef tallow diet than in the safflower oil diet $(p<0.05)$, and it decreased significantly with meal ingestion only in the beef tallow-fed rats $(p<0.05)$ (Fig. 1). LPL activity in the soleus muscle before a meal was lower in the beef tallow diet group $(p<0.05)$, although the difference was not significant between postprandial values $(p<0.2)$. It decreased significantly with meal ingestion only in the safflower oil diet $(p<0.05)$ (Fig. 1).

Fatty acid composition of plasma membrane. The fatty acid composition of plasma membrane is shown in Table 4. Whatever the tissues, linoleic acid $(18: 2 n$ - 
Table 3. Effect of the dietary fats on serum glucose, insulin, and triacylglycerol concentrations before and after a meal. ${ }^{1}$

\begin{tabular}{ccc}
\hline & \multicolumn{2}{c}{ Diet group } \\
\cline { 2 - 3 } & Safflower oil & Beef tallow \\
\hline Glucose $(\mathrm{mg} / \mathrm{dl})$ & $116 \pm 5$ & $121 \pm 3$ \\
$\quad$ Preprandial & $116 \pm 3^{\dagger}$ & $171 \pm 6^{8}$ \\
Postprandial & $14 \pm 2$ & $26 \pm 2^{*}$ \\
Insulin (uU/ml) & $32 \pm 2^{\dagger}$ & $47 \pm 3^{* \dagger}$ \\
$\quad$ Preprandial & & $146 \pm 14^{*}$ \\
$\quad$ Postprandial & $71 \pm 3$ & $442 \pm 65^{* \dagger}$ \\
Triacylglycerol (mg/dl) & $192 \pm 18^{\dagger}$ & \\
$\quad$ Preprandial & Postprandial &
\end{tabular}

${ }^{1}$ Values are means \pm SE for 10 rats. ${ }^{*}$ Statistically significant difference $(p<0.05)$ from the safflower oil deit group. ${ }^{\S}$ Statistically significant difference $(p<0.05)$ from the preprandial value $(2 \times 2$ ANOVA and Sheffe's test $)$.

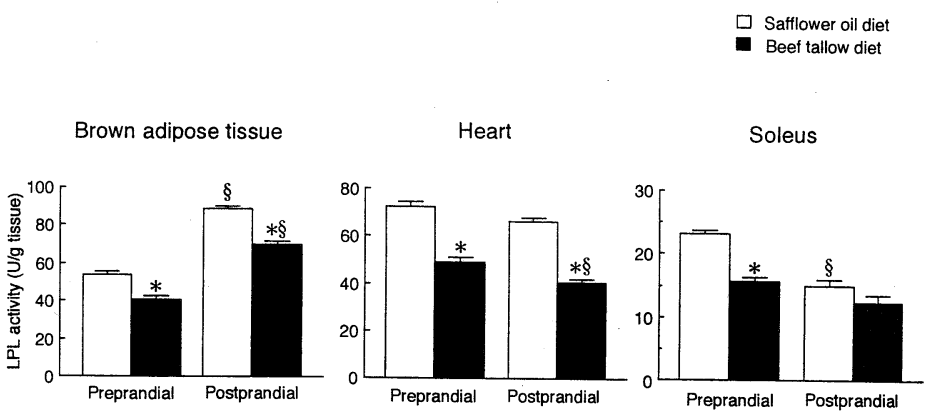

Fig. 1. Lipoprotein lipase activities of IBAT, heart, and soleus muscle in rats fed the beef tallow diet or the safflower oil diet before and after meals. Values are means and SE for 10 rats. * Statistically significant difference from the safflower oil diet group. ${ }^{8}$ Statistically significant difference from the preprandial value. Differences with $p<0.05$ (ANOVA and Scheffe's test) were considered to be significant.

$6)$ in plasma membranes was significantly lower and myristic acid $(14: 0)$, myristoleic acid (14:1n-9), palmitic acid (16:0), palmitoleic acid (16:1n-9), oleic acid $(18: 1 n-9)$, icosenoic acid $(20: 1 n-9)$, and icosatrienoic acid $(20: 3 n-3)$ in plasma membranes were significantly higher in the beef tallow diet group than in the safflower oil diet group $(p<0.01)$. In the IBAT, stearic acid $(18: 0)$ in plasma membranes was significantly higher in the beef tallow diet group $(p<0.01)$. In the heart, arachidic acid $(20: 0)$ in plasma membrane was higher and the proportion of arachidonic acid $(20: 4 n-6)$ was lower in the beef tallow diet group $(p<0.01)$. The $\mathrm{P} / \mathrm{S}$ ratios (total polyunsaturated fatty acids/total saturated fatty acids) of plasma membranes in the IBAT, heart, and soleus muscle were significantly lower in the 
Table 4. Effect of the dietary fats on fatty acid composition of plasma membrane. ${ }^{1}$

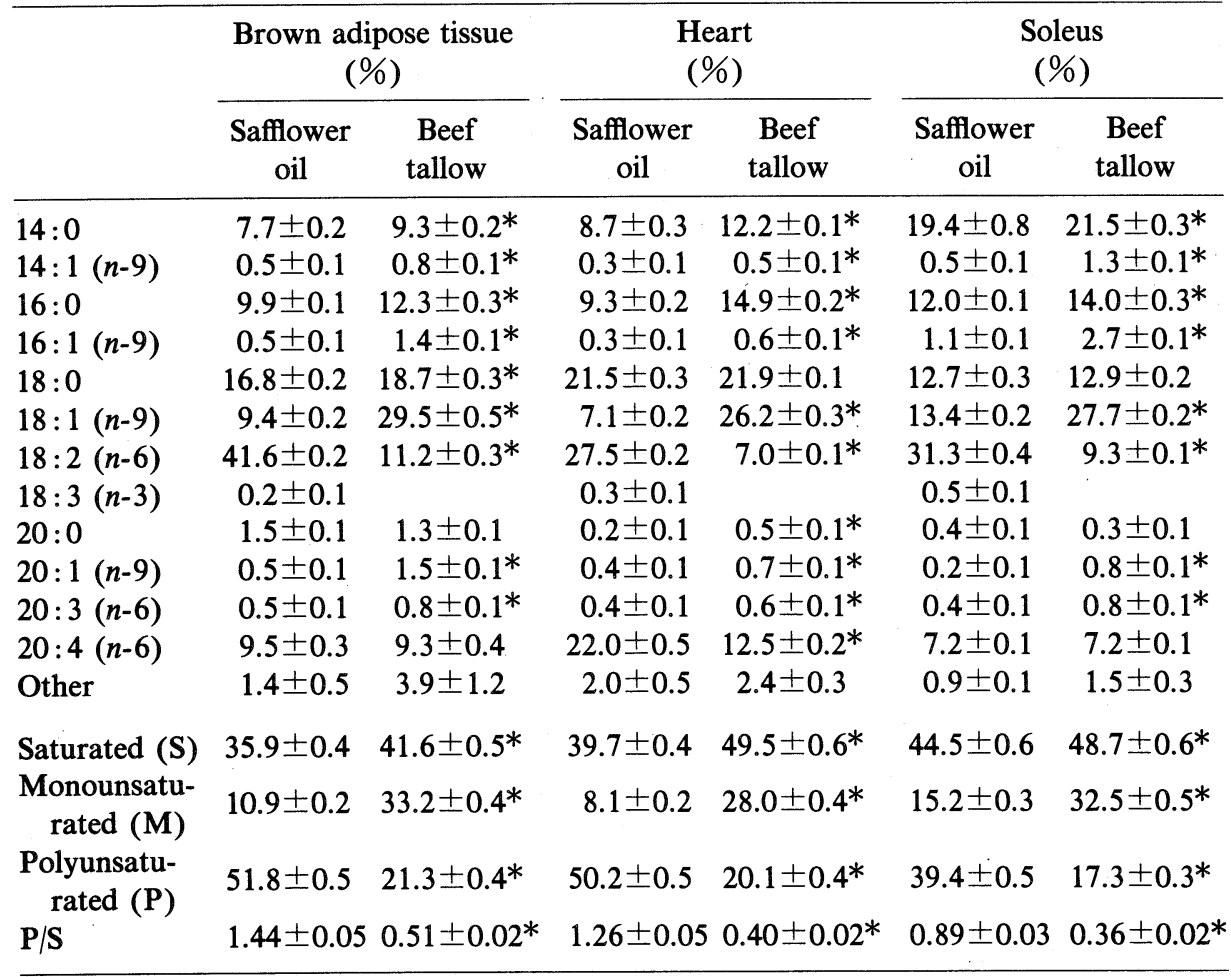

${ }^{1}$ Values are means $\pm \mathrm{SE}$ for 10 rats. ${ }^{*}$ Statistically significant difference $(p<0.01)$ from the safflower oil diet group (Student's $t$-test).

Table 5. Effect of the dietary fats on degrees of fluorescence polarization of diphenylhexatrien in plasma membranes. ${ }^{1}$

\begin{tabular}{lcc}
\hline & \multicolumn{2}{c}{ Diet group } \\
\cline { 2 - 3 } & Safflower oil & Beef tallow \\
\hline Brown adipose tissue & $0.30 \pm 0.01$ & $0.42 \pm 0.02^{*}$ \\
Heart & $0.25 \pm 0.01$ & $0.31 \pm 0.02^{*}$ \\
Soleus muscle & $0.29 \pm 0.01$ & $0.36 \pm 0.01^{*}$ \\
\hline
\end{tabular}

${ }^{1}$ Values are means \pm SE for 10 rats. * Statistically significant difference $(p<0.01)$ from the safflower oil diet group (Student's $t$-test).

beef tallow diet group than in the safflower oil diet group $(p<0.01)$ (Table 4).

Membrane fluidity. Fluidity of plasma membrane was assessed by fluorescence polarization $(P)$ of DPH probes (Table 5). Whatever the tissue, membrane fluidities were lower in the beef tallow diet group than in the safflower oil diet group $(p<0.01)$. 
$\beta$-Adrenergic receptor binding. $\beta$-Adrenergic receptor binding was determined with [ $\left.{ }^{125} \mathrm{I}\right]$ iodocyanopindolol. Plasma membranes from the IBAT, heart, and soleus muscle of rats fed the beef tallow diet group or the safflower oil diet

Table 6. Effect of the dietary fats on $\beta$-adrenoreceptor binding of brown adipose tissue, heart, and soleus muscle. ${ }^{1}$

\begin{tabular}{|c|c|c|}
\hline & \multicolumn{2}{|c|}{ Diet group } \\
\hline & Safflower oil & Beef tallow \\
\hline \multicolumn{3}{|l|}{ Brown adipose tissue } \\
\hline$K_{\mathrm{d}}(\mathrm{pM})$ & $202 \pm 37$ & $479 \pm 115^{*}$ \\
\hline$B_{\max }($ fmol/mg protein $)$ & $220 \pm 41$ & $297 \pm 42$ \\
\hline \multicolumn{3}{|l|}{ Heart } \\
\hline$K_{\mathrm{d}}(\mathrm{pM})$ & $67 \pm 8$ & $104 \pm 12 *$ \\
\hline$B_{\max }($ fmol/mg protein $)$ & $97 \pm 12$ & $131 \pm 15$ \\
\hline \multicolumn{3}{|l|}{ Soleus muscle } \\
\hline$K_{\mathrm{d}}(\mathrm{pM})$ & $103 \pm 9$ & $198 \pm 39 *$ \\
\hline$B_{\max }(\mathrm{fmol} / \mathrm{mg}$ protein $)$ & $164 \pm 15$ & $118 \pm 23$ \\
\hline
\end{tabular}

Table 7. Effect of the dietary fats on NE turnover of brown adipose tissue, heart, and soleus muscle. ${ }^{1}$

\begin{tabular}{|c|c|c|}
\hline & \multicolumn{2}{|c|}{ Diet group } \\
\hline & Safflower oil & Beef tallow \\
\hline \multicolumn{3}{|l|}{ Brown adipose tissue } \\
\hline $\mathrm{NE}_{0}$ (ng/tissue) & $997 \pm 27$ & $861 \pm 7 *$ \\
\hline$k(\% / \mathrm{h})$ & $12.4 \pm 0.5$ & $10.4 \pm 0.7 *$ \\
\hline$t_{1 / 2}(\mathrm{~h})$ & $5.6 \pm 0.2$ & $6.7 \pm 0.4^{*}$ \\
\hline $\mathrm{NE}_{\mathrm{t}}(\mathrm{ng} / \mathrm{tissue} / \mathrm{h})$ & $124 \pm 5$ & $90 \pm 6^{*}$ \\
\hline \multicolumn{3}{|l|}{ Heart } \\
\hline $\mathrm{NE}_{0}$ (ng/tissue) & $809 \pm 36$ & $643 \pm 8^{*}$ \\
\hline$k(\% / h)$ & $11.5 \pm 1.4$ & $7.4 \pm 1.1^{*}$ \\
\hline$t_{1 / 2}(\mathrm{~h})$ & $6.0 \pm 0.6$ & $9.4 \pm 1.3^{*}$ \\
\hline $\mathrm{NE}_{\mathrm{t}}(\mathrm{ng} /$ tissue $/ \mathrm{h})$ & $93 \pm 11$ & $48 \pm 7 *$ \\
\hline \multicolumn{3}{|l|}{ Soleus muscle } \\
\hline $\mathrm{NE}_{0}$ (ng/tissue) & $6.9 \pm 0.3$ & $6.2 \pm 0.3$ \\
\hline$k(\% / h)$ & $14.3 \pm 3.0$ & $7.6 \pm 1.8^{*}$ \\
\hline$t_{1 / 2}(\mathrm{~h})$ & $4.9 \pm 0.9$ & $9.1 \pm 1.8^{*}$ \\
\hline $\mathrm{NE}_{\mathrm{t}}(\mathrm{ng} /$ tissue/h) & $1.0 \pm 0.2$ & $0.5 \pm 0.1 *$ \\
\hline
\end{tabular}


group were incubated with increasing concentrations of radioligands. The binding process was saturable (data not shown). Mean maximal binding sites $\left(\boldsymbol{B}_{\max }\right)$ and binding affinities $\left(K_{\mathrm{d}}\right)$ are given in Table $6 . \beta$-Adrenergic receptor binding affinity for $\left[{ }^{125} I\right]$ iodocyanopindolol in the IBAT, the heart, and the soleus muscle were significantly lower (42\% in the IBAT, $64 \%$ in the heart, and $52 \%$ in the soleus muscle) in the beef tallow diet group than in the safflower oil diet group $(p<0.05)$ (Table 6). However, maximal numbers of $\beta$-adrenergic receptors in the IBAT, the heart, and the soleus muscle were not different between two diet groups (Table 6).

Experiment 2: Effects of dietary fats on the sympathetic activities of various organs

Body weight, body fat, and tissue weights. Data of body weight, body fat, and tissue weights were similar to those in experiment 1 (see Table 2).

$N E$ content and turnover. The basal NE content in the IBAT and heart were significantly lower in the beef tallow diet group than in the safflower oil diet group $(p<0.05)$, whereas that in the soleus muscle was the same between the two dietary groups (Table 7). Whatever the tissue, fractional turnover and NE turnover rates were significantly lower and half lives of NE were higher in the beef tallow diet group than in the safflower oil diet group $(p<0.05)$ (Table 7).

\section{DISCUSSION}

Our previous study showed that intake of a beef tallow diet promotes larger body fat accumulation compared with intake of a safflower oil diet in rats, and suggested that this effect of a beef tallow diet is at least in parts ascribed to lower LPL activities in the heart and soleus muscle and lower diet-induced thermogenesis (8). Since the IBAT plays important roles in diet-induced thermogenesis and fat oxidation, LPL activity in the IBAT in addition to heart and soleus muscle was analyzed in the present study. The IBAT, heart, and soleus muscle of rats fed the beef tallow diet appeared to have lower LPL activities before and after a meal than those of rats fed the safflower oil diet, suggesting that blood triacylglycerol was taken into these tissues at a lower rate in the beef tallow diet group than in the safflower oil diet group. This view is compatible with the higher level of serum triacylglycerol in the former than the latter. The increase of serum triacylglycerol as a result of saturated fat intake has been noted by others (23).

The present results clearly demonstrate that the binding affinities of $\beta$ adrenergic receptor and NE turnover rates in the IBAT, heart, and soleus muscle were lower in the beef tallow diet group than in the safflower oil diet group. Because both groups of rats consumed diets with the same amount of metabolizable energy throughout the experimental period, the difference in the NE turnover rates and the $\beta$-adrenergic receptor binding affinities between two dietary groups were ascribed to different dietary fats. $\beta$-Adrenergic receptor was coupled with adenylate cyclase in plasma membrane, when catecholamines bind to $\beta$-adrenergic receptor, adenylate cyclase is activated (24). Adenylate cyclase catalyzes the 
production of cyclic AMP, an intracellular messenger, which in turn produces various physiological actions. Carneheim et al. $(6,7)$ suggested that cold exposure resulted in an increase in LPL activity in rat brown adipose tissue caused by $\beta$-adrenergic stimulation of LPL gene transcription. Radomski and Orme (4) reported that cold exposure activated LPL in various tissues due to response to norepinephrine. From these viewpoints, the sympathetic nerve- $\beta$-adrenergic receptor-cAMP system may play a regulatory role in LPL activities. On the other hand, maximal numbers of $\beta$-adrenergic receptors in the IBAT, heart, and soleus muscle were not significantly different between the two dietary groups. It was suggested that the dietary fats induced alteration in the receptor binding affinity rather than the receptor number.

$\beta$-Adrenergic receptor binding is altered by the membrane fluidity (25). Wince and Rutledge (25) suggested that the lower binding of $\beta$-adrenergic receptor was caused by the lower membrane fluidity. Our present findings support these studies.

Membrane fluidity is affected by the membrane fatty acid composition (26, 27). The presence of polyunsaturated fatty acids in the lipid bilayer increases the fluidity. In contract, saturated fatty acids reduce fluidity because of the absence of double bonds. Consequently, the $\mathrm{P} / \mathrm{S}$ ratio is known to be representative of the contribution of fatty acid to membrane fluidity. In this experiment, the $\mathbf{P} / \mathrm{S}$ ratios of plasma membranes in IBAT, heart, and soleus muscle were lower in the beef tallow diet group than in the safflower oil diet group. These results were parallel to those of membrane fluidity.

LPL activity is also regulated by nutritional and hormonal factors (1). In the present study, LPL activitiy in the IBAT increased, but those in the heart and soleus muscle decreased with meal ingestion. It is suggested that the increase in LPL activitiy in brown adipose tissue after a meal supplies triacylglycerol fatty acids to brown adipose tissue from bloodstream in order to cause diet-induced thermogenesis.

We previously reported that sympathetic activity in the pancreas was lower in the beef tallow diet group than in the safflower oil diet group, resulting in higher serum insulin level in the former (28). Our present study confirmed these results. Serum insulin inhibits LPL activities in heart and soleus muscle by a mechanism different from sympathetic nervous system in these tissues, possibly, by affecting post-transcriptional regulation of the LPL gene (1).

It is known that serum insulin activates fat synthesis in white adipose tissues (29). Lipogenesis is lower in rats fed a high fat diet than in rats fed a low fat diet (30), however, we used a high-fat and low-carbohydrate diet $(45,35$, and $20 \%$ of energy as fat, carbohydrate, and protein, respectively) in this experiment. From these viewpoints, it is to be understood that lipogenesis in white adipose tissues are minor factors in body fat accumulation by the intake of beef tallow diet.

In conclusion, the present study demonstrates that dietary saturated fats are modulators of the body fat accumulation in the beef tallow diet group, at least in 
part, with relation to lower LPL activities in the IBAT, heart, and soleus muscle resulted from lower NE turnover rates and $\beta$-adrenergic receptor binding affinities and suggest that saturated fats reduce membrane fluidity by reducing the $\mathrm{P} / \mathrm{S}$ ratios in these tissues. Since there may be other factors in the regulation of body fat accumulation, a detailed study is required to clarify this mechanism.

We thank Mrs. Kazumi Takagi for animal care and Mr. Masafumi Tanigawa for technical assistance.

\section{REFERENCES}

1) Braun, J. E. A., and Severson, D. L. (1992): Regulation of synthesis, processing and translocation of lipoprotein lipase. Biochem. J., 287, 337-347.

2) Engelber, H. (1966): Mechanisms involved in the reduction of serum triglycerides in man upon adding unsaturated fats to the normal diet. Metabolism, 15, 796-807.

3) Bagdade, J. D., Hazzard, W. R., and Carlin, J. (1970): Effect of unsaturated dietary fat on plasma lipoprotein lipase activity in normal and hyperlipidemic states. Metabolism, 19, 1020-1024.

4) Radomski, M. W., and Orme, T. (1971): Response of lipoprotein lipase in various tissues to cold exposure. Am. J. Physiol., 220, 1852-1856.

5). Miller, W. C., Gorski, J., Oscai, L. B., and Palmer, W. K. (1989): Epinephrine activation of heparin-nonreleasable lipoprotein lipase in 3 skeletal muscle fiber types of the rat. Biochem. Biophys. Res. Commun., 164, 615-619.

6) Carneheim, C., Nedergaard, J., and Cannon, B. (1984): $\beta$-Adrenergic stimulation of lipoprotein lipase in rat brown adipose tissue during acclimation to cold. Am. J. Physiol., 246, E327-E333.

7) Carneheim, C., Nedergaard, J., and Cannon, B. (1988): Cold-induced $\beta$-adrenergic recruitment of lipoprotein lipase in brown fat is due to increased transcription. Am. J. Physiol., 254, E155-E161.

8) Shimomura, Y., Tamura, T., and Suzuki, M. (1990): Less body fat accumulation in rats fed a safflower oil diet than in rats fed a beef tallow diet. J. Nutr., 120, 1291-1296.

9) Mickelsen, O., and Anderson, A. A. (1959): A method for preparing intact animals for carcass analysis. J. Lab. Clin. Med., 53, 282-290.

10) Mori, N., Murase, T., Yamada, N., Arakawa, N., and Takaku, F. (1984): Wide variations of plasma triglyceride concentrations in guinea pigs. Lipids, 19, 978-981.

11) Nilsson-Ehle, P., and Schotz, M. C. (1976): A stable, radioactive substrate emulsion for assay of lipoprotein lipase. J. Lipid Res., 17, 536-541.

12) Scarpace, P. J., and Abrass, I. B. (1989): Thyroid hormone regulation of rat heart, lymphocyte, and lung $\beta$-adrenergic receptors. Endocrinology, 108, 1007-1011.

13) Bradford, M. A. (1976): Rapid and sensitive method for the quantitation of microgram quantities of protein utilizing the principle of protein dye binding. Anal. Biochem., 72, 248-254.

14) Folch, J., Lees, M., and Sloane-Stanley, G. A. (1957): Simple method for the isolation and purification of total lipids from animal tissues. J. Biol. Chem., 226, 497-509.

15) Nelson, G. J., Kelley, D. S., and Hunt, J. E. (1986): Effect of nutritional status on the fatty acid composition of rat liver and cultured hepatocytes. Lipid, 21, 454-459. 
16) Nicolas, C., Demarne, Y., Lecourtier, M. J., and Lhuillery, C. (1990): Specific alterations in different adipose tissues of pig adipocyte plasma membrane structure by dietary lipid. Int. J. Obes., 14, 537-549.

17) Shinitzky, M., and Barenholz, Y. (1974): Dynamics of the hydrocarbon layer in liposomes of lecithin and sphingomyelin containing dicetylphosphate. J. Biol. Chem., 249, 2652-2657.

18) Bylund, D. B., and Snyder, S. H. (1976): Beta adrenergic receptor binding in membrane preparations from mammalian brain. Mol. Pharmacol., 12, 568-580.

19) Scatchard, G. (1949): The attractions of proteins for small molecules and ions. Ann. N.Y. Acad. Sci., 51, 660-672.

20) Refshauge, C., Kissinger, P. T., Dreiling, R., Blank, L., Freeman, R., and Adams, R. N. (1974): New high performance liquid chromatographic analysis of brain catecholamines. Life Sci., 14, 311-322.

21) Brodie, B. B., Costa, E., Dlabac, A., Neff, N. H., and Smookler, H. H. (1966): Application of steady state kinetics to the estimation of synthesis rate and turnover time of tissue catecholamines. J. Pharmacol. Exp. Ther., 154, 493-498.

22) Scheffe, H. (1959): The Analysis of Variance, Wiley, New York.

23) Paik, H., and Yearick, E. S. (1978): The influence of dietary fat and meal frequency on lipoprotein lipase and hormone-sensitive lipase in rat adipose tissue. J. Nutr., 108, 1798-1805.

24) Himms-Hagen, J. (1984): Thermogenesis in brown adipose tissue as energy buffer. $N$. Engl. J. Med., 311, 1549-1558.

25) Wince, L. C., and Rutledge, C. O. (1981): The effect of dietary lipid on binding of $\left[{ }^{3} \mathrm{H}\right]$ dihydroalprenolol and adenylate cyclase activity in rat atria. J. Pharmacol. Exp. Ther., 219, 625-631.

26) Nicolas, C., Demarne, Y., Lecourtier, M. J., and Lhuillery, C. (1990): Specific alterations in different adipose tissues of pig adipocyte plasma membrane structure by dietary lipids. Int. J. Obes., 14, 537-549.

27) Nicolas, C., Lacasa, D., Giudicelli, Y., Demarne, Y., Agli, B., Lecourtier, M. J., and Lhuillery, C. (1991): Dietary ( $n-6)$ polyunsaturated fatty acids affect $\beta$-adrenergic receptor binding and adenylate cyclase activity in pig adipocyte plasma membrane. $J$. Nutr., 121, 1179-1186.

28) Matsuo, T., Shimomura ,Y., Saitoh, S., Tokuyama, K., and Suzuki, M. (1993): Lower sympathetic activity in rats fed a beef tallow diet than in rats fed a safflower oil diet, in Abstracts XV International Congress of Nutrition Adelaid 2, p. 775.

29) Bazin, R., and Lavau, M. (1982): Development of hepatic and adipose tissue lipogenic enzymes and insulinemia during suckling and weaning on to a high-fat diet in Zucker rats. J. Lipid Res., 23, 839-849.

30) Toussant, M. J., Wilson, M. D., and Clarke, S. D. (1981): Coordinate suppression of liver acetyl-CoA carboxylase and fatty acid synthetase by polyunsaturated fat. $J$. Nutr., 111, 146-153. 